\title{
Imagens Mágicas
}

\section{Ana Angélica Teixeira Ferreira da Costa}

Universidade do Estado do Rio de Janeiro (UER])

\section{Resumo}

A partir das obras e atividades do eixo curatorial Imagem Mágica, dentro do $10^{\circ}$ Festival Hercule Florence de Fotografia, este artigo levanta algumas inquietações sobre o que significa trabalhar com o fenômeno da câmera obscura e com métodos artesanais de produção de imagens em meio à cultura digital contemporânea. Ao longo do texto, serão apresentadas as obras expostas e seus processos, assim como considerações elaboradas pelos artistas participantes e por outros pensadores que têm se dedicado ao assunto.

Palavras-chave: Fotografia contemporânea; Câmera obscura; Pinhole; Fotografia artesanal.

\section{Magic Pictures}

\begin{abstract}
This article raises some questions about what it means to work with the obscure camera phenomenon and with analogical methods to produce images within the contemporary digital culture. The article was written based on the works and activities developed by the curatorial branch named Magic Image during the 10th Hercule Florence Photography Festival in April/2017, in Campinas, Brazil. Throughout the text, works are exposed and their processes are presented, as well as reflections of the participating artists and other researchers who have didicated themselves to the subject.
\end{abstract}

Keywords: Contemporary photography; Obscure camera; Pinhole; Alternative photography. 


\section{Dossiê Fotografia, Arte e História \\ na atualidade: relações praticadas}

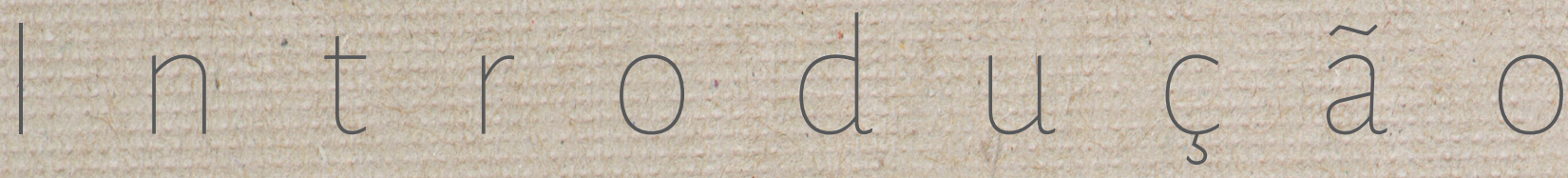

\section{1 pesar das inovações e revoluções tecnológicas pelas quais o mundo passou nas últimas décadas, é possível observar que, para alguns artistas e educadores, as metodologias mais arcaicas de produção de imagens levantam questões acerca das imagens na arte}

e no mundo contemporâneo.

Para além do efeito estético, os artistas e educadores que escolhem trabalhar com os mais simples dos aparelhos produtores de imagens (a câmera pinhole ${ }^{1}$ ou estenopeica ${ }^{2}$, por um lado, e a câmera obscura, por outro), parecem apontar para uma vontade de reconexão com o material, o originário, ou para a necessidade de produzir um aparelho específico, que gere imagens não padronizadas.

O princípio da câmera obscura ${ }^{3}$ é o fenômeno ótico responsável pela formação da imagem no interior de todos os dispositivos produtores de imagens, seja uma câmera analógica, digital ou mesmo um smartphone. Qualquer espaço ou recipiente totalmente escuro, no qual a luz atinja o interior por um pequeno orifício, é capaz de formar uma imagem. As características do ambiente

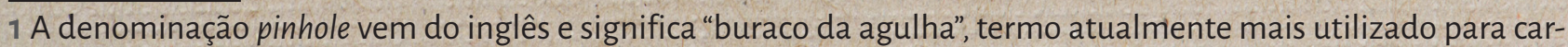
acterizar esse tipo de câmera, ao lado de fotografia estenopeica, utilizado nos países de língua francesa (sténopé) e espanhola (fotografia estenopeica). Também chamada de câmera de orifício ou câmera de latinha, nos países de língua portuguesa, a pinhole é uma câmera fotográfica sem lentes objetivas, na qual um pequeno furo de agulha, de aproximadamente $4 \mathrm{~mm}$ de diâmetro, feito em papel laminado, substitui o diafragma de uma câmera convencional. O obturador, mecanismo disparado no momento do "clic", resṕonsável por permitir a entrada de luz no interior da câmera, é geralmente substituído por um pedaço de fita isolante.

2 Estenopeica, segundo Maria Helena Saburido Villar (2008, p. 14), pesquisadora que desenvolveu um extenso estudo acerca deste tipo de fotografia no Brasil, "é a terminologia adotada para definir imagens obtidas sem a utilização de lentes. [...] No caso da fotografia estenopeica, no lugar das objetivas das câmeras fotográficas tradicionais é apenas um orifício que forma a imagem. A palavra estenopeica vem de 'estenopo' que é o nome que se dá ao pequeno furo por onde passa a luz que irá formar a imagem. O termo tem origem na língua grega -stenos, estreito, e opê, furo ou ôps, olho".

3 Segundo Maria Helena Saburido Villar (2008, p. 15), "Câmera obscura é o termo latino para câmera escura - (câmera - compartimento ou aposento de uma casa e, em especial, o quarto de dormir; e obscuro (a) - falta de luz; pouco claro; sombrio, tenebroso). A expressão é utilizada para designar o princípio de formação de imagens através de orifícios no interior de compartimentos escuros. Inicialmente as Câmeras obscuras eram utilizadas para observação de eclipses. Posteriormente, na forma de pequenas caixas portáteis, foram utilizadas para auxiliar no desenho. Nessas caixas foram adicionadas lentes no lugar do orifício, para melhorar a qualidade da imagem, e uma superfície translúcida do lado oposto, para decalcar a imagem. No início do século XIX, com a introdução de um material sensível na face onde se forma a imagem, ela se transformou na câmera fotográfica". 


\section{A exposição Imagem}

Mágica, que empresta o termo para o título deste. artigo bem como oferece a oportunidade de elaboração deste estudo, compôs um dos eixos curatoriais do $10^{\circ}$ Festival Hercule Florence de Fotografia, que aconteceu na cidade de Campinas, de 18 a 22 abril de 2017 . Esse eixo curatorial teve como objetivo refletir sobre os processos que envolvem a fotografia partindo do princípio da câmera obscura, das câmeras artesanais e dos mecanismos de formação da imagem. e da superfície em que a luz é projetada influenciam diretamente as características da imagem, ampliando o leque de possibilidades - materiais e conceituais - a se considerar em um projeto fotográfico com câmeras artesanais. Por meio da câmera obscura e das câmeras fotográficas artesanais podemos observar com clareza o processo de formação da imagem. A câmera pinhole retoma, portanto, um vínculo com o fazer, tão presente na Arte Moderna, que retorna não apenas a um fazer manual, como também maquínico, e problematiza o "ato fotográfico", o ato da "tomada" da imagem fotográfica, acentuando seu caráter performático e processual.

A exposição Imagem Mágica, que empresta o termo para o título deste artigo bem como oferece a oportunidade de elaboração deste estudo, compôs um dos eixos curatoriais do $10^{\circ}$ Festival Hercule Florence de Fotografia, que aconteceu na cidade de Campinas, de 18 a 22 abril de 2017. Esse eixo curatorial teve como objetivo refletir sobre os processos que envolvem a fotografia partindo do princípio da câmera obscura, das câmeras artesanais e dos mecanismos de formação da imagem. Para tanto, se estruturou em torno de oficinas dos artistas participantes, de uma mesa no seminário temático do Festival, que aconteceu no Auditório do Instituto de Artes; e da exposição homônima.

Composta por fotografias e objetos feitos com câmeras artesanais, ações e intervenções em espaços abertos, a mostra reuniu fotógrafos e artistas de diferentes estados brasileiros: Dirceu Maués (PA/MG), Luiz Alberto Guimarães (RJ), Monica Mansur (RJ) e Miguel Chikaoka (PA). A ideia era convidar o visitante a protagonizar a descoberta dos princípios físico-ópticos básicos de formação da imagem e transformar o espaço expositivo em local de experimentação e aprendizado, evidenciando o caráter processual e a estrutura das obras. A localização na Estação Cultura, local de fluxo intenso de trabalhadores e de pessoas que utilizam o comércio e serviços do centro da cidade, foi decisiva para a interação com esse público que, de maneira geral, pouco tem acesso a obras e processos artísticos em seu cotidiano. A montagem das obras 
no saguão teve como base a utilização de andaimes para organizar o espaço expositivo como forma de evidenciar tanto a precariedade do espaço (em consonância com o conteúdo exposto) quanto a base estrutural das paredes e do painel montado.

Jean-Marie Schaeffer (1996, p. 143), em seu livro A imagem precária: sobre o dispositivo fotográfico, apresenta a fotografia como uma arte precária por estar ligada "à contingência, ao caráter arriscado da gênese da imagem". As obras aqui apresentadas radicalizam essa precariedade ao fazerem uso de câmeras sem visor e com a ampliação do tempo de exposição à luz. Assim, nas imagens expostas em Imagem Mágica, a precariedade da fotografia é intensificada através da precariedade dos materiais utilizados e da importância do processo na obra final (Imagens 1 e 2).

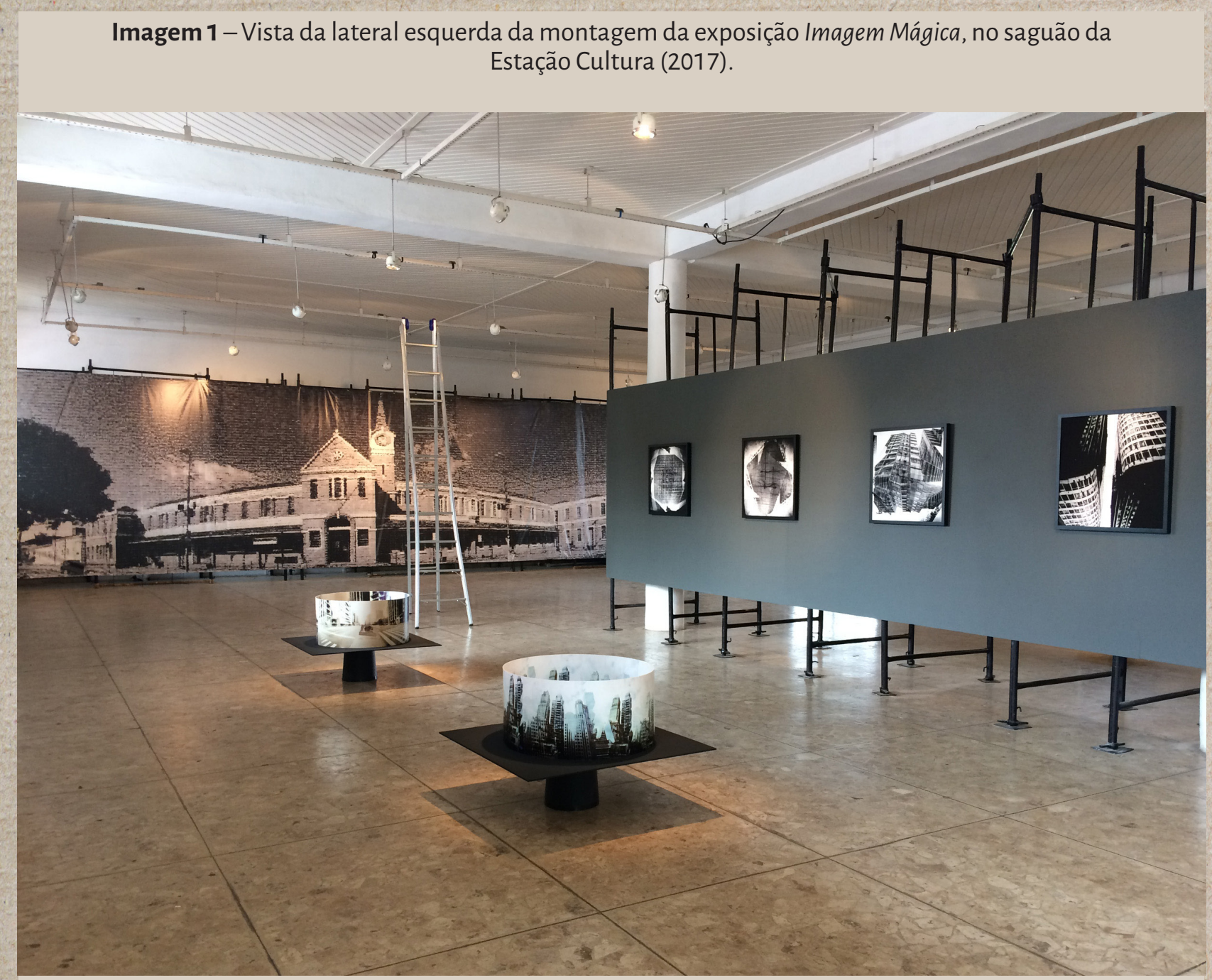

Fonte: Elaborada pela autora.

Ao fundo, encontra-se o painel "Urublues Campinas", de Miguel Chikaoka. Em primeiro plano, encontram-se os "Panoramas imaginários", de Monica Mansur, e nas paredes montadas pelos andaimes, as imagens da série "Cuba Libre", de Luiz Alberto Guimarães. 


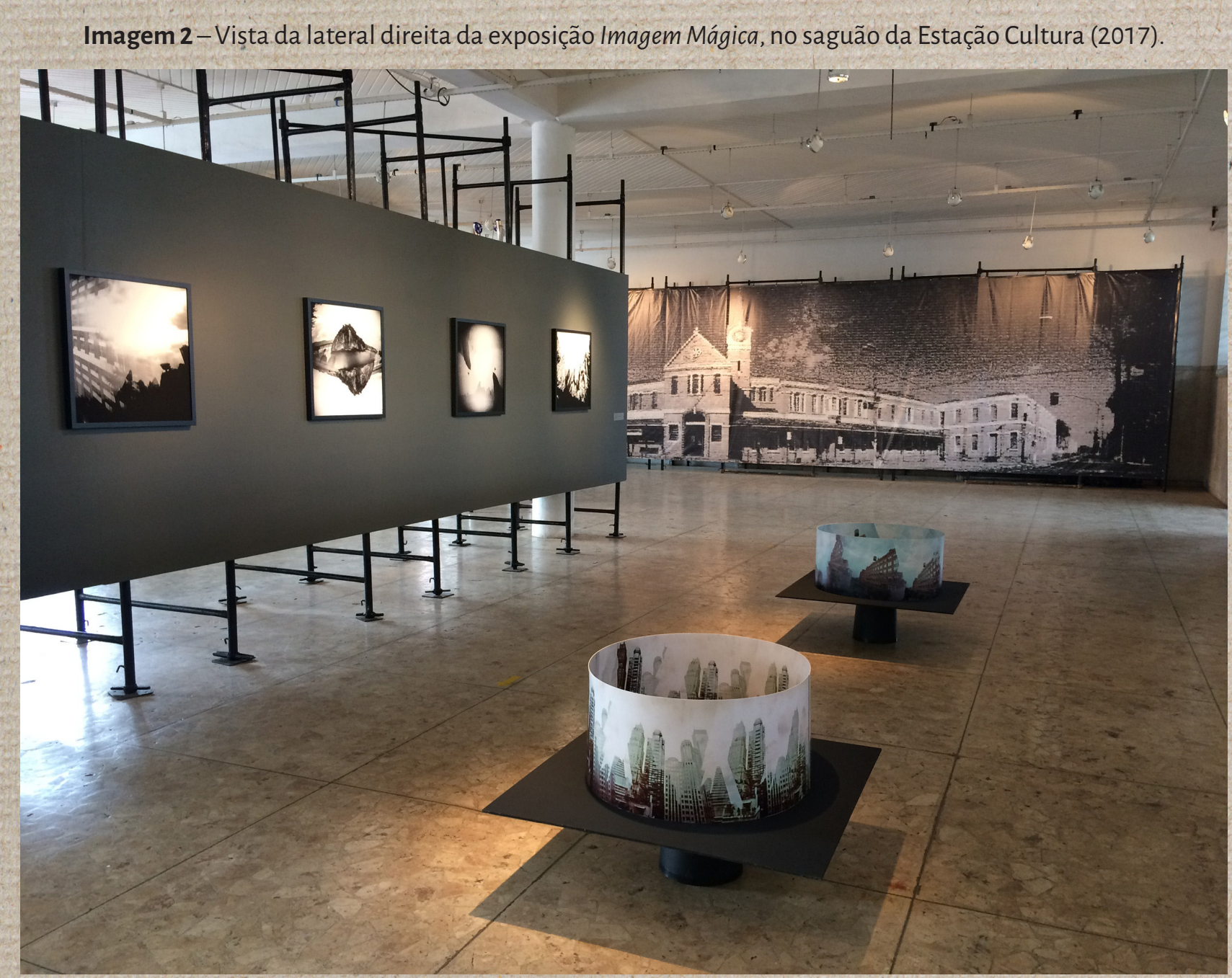

Fonte: Festival Hercule Florence de Fotografia (2017). Fotografia de Ricardo Lima (acervo pessoal).

Assim, as ações do eixo curatorial Imagem Mágica foram estruturadas a partir de duas linhas principais de atuação dos fotógrafos e artistas interessados na incursão da imagem fotográfica constituída pelos meios mais artesanais e analógicos. Em ambas, há o interesse pela vivência, pela descoberta sensível e pela análise do fenômeno da formação da imagem, visando à reflexão sobre o papel da imagem na arte e na vida contemporânea. A primeira linha de atuação contemplou a exposição, com imagens e obras prontas feitas por câmeras artesanais, e a segunda, a construção de obras instalativas dentro de oficinas durante o $10^{\circ} \mathrm{Festival} \mathrm{Hercule}$ Florence de Fotografia de Campinas.

Este estudo pretende suscitar algumas reflexões acerca do significado, nos dias de hoje, dessa retomada de experimentações artísticas e educativas em torno do fenômeno da câmera obscura, e discorrer sobre as obras expostas. Para tanto, será dividido em cinco partes: em um primeiro momento são levantadas inquietações acerca do que significa, hoje, a pesquisa artística em torno de experimentos que remontam à origem da fotografia; depois, são abordadas 


\section{Fotografia, Arte e História \\ na atualidade: relações praticadas}

as obras dos artistas participantes da exposição Imagem Mágica, a partir do que identificamos como quatro eixos principais: experimentos com a câmera obscura em obras instalativas; experimentos com a forma (anamorfoses); experimentos com o tempo (no caso, com o panorama); e processos colaborativos em projetos educativos e sociais, realizando obras coletivas.

\section{Voltar à câmera escura?}

A crença no progresso material e nas utopias políticas promoveu, até o entreguerras, um fascínio pela velocidade, que encontrou nos dispositivos imagéticos de última geração um potente aliado. Por sua vez, principalmente a partir dos anos 1950, acompanhamos o desenvolvimento, principalmente entre cineastas e artistas experimentais, de uma estética do lento e da desaceleração (FATORELLI, 2016, p. 44).

Ao voltar a atenção para a produção recente de artistas brasileiros que desenvolvem pesquisas com câmeras escuras e câmeras fotográficas artesanais, não podemos deixar de levantar algumas questões: qual o motivo deste aparente "retorno" à câmera escura e aos primórdios da fotografia? Por que, hoje em dia, os filtros mais utilizados em aplicativos de tratamento e veiculação de imagens, como Instagram, são justamente os que simulam uma visualidade do filme fotográfico analógico? Apesar de não serem diretamente tratadas na exposição Imagem Mágica, tais inquietações permeiam o pensamento de muitos artistas e pensadores que trabaIham com a produção artesanal e analógica de imagens.

No caso do trabalho aqui estudado, essa volta, o recuar para melhor compreender a contemporaneidade, parece se dar como um passo em direção aos mecanismos primeiros de produção de imagem, ao modo mais simples de produção encontradó em qualquer imagem fotográfica ou cinematográfica. Tentar compreender como aconteceu a transformação dos dispositivos de visualização e realização de imagens (e dos sujeitos que eles acessavam ou que a eles tinham acesso e neles agiam) constitui, neste sentido, um movimento para pensar a atual complexidade imagética contemporânea. Dentro desse movimento, Julio Bressane, importante cineasta experimental brasileiro, afirma a necessidade de volta às imagens primeiras:

A dialética (suprema arte de perguntar e responder) da busca de novas tecnologias de criação da imagem-música nos obriga a que quanto mais se avança, no sentido de fragmentar a sensibilidade e a inteligência, mais é preciso recuar às nascentes onde o inteligente e o sensível encontram o curioso. Novo (BRESSANE, 1996, p. 79). 
E completa:

Da realidade virtual eletrônica, da computação gráfica, da holografia, é preciso voltar à sombra da caverna, [...] e aos primeiros rituais sensíveis de expressão artística. Quanto mais imagemmáquina mais necessário será o desenho rupestre, esse primeiro cantão intelectual de nosso mundo (BRESSANE, 1996, p. 79).

Outra posição um tanto convergente em relação à de Bressane é a de Vilém Flusser (2009) que, ao alertar-nos sobre a necessidade de uma filosofia da fotografia, propõe como única saída o desvendamento da caixa-preta dos aparelhos, ou seja, o desvendamento e intervenção em seus mecanismos (dispositivos), tanto no momento de produção quanto no de veiculação das imagens produzidas. Pois, segundo o filósofo, com o desenvolvimento tecnológico foi-se perdendo o campo emocional mais ligado à experiência direta com os materiais. O fascínio da experiência de ver a formação da imagem e de construir um dispositivo com características próprias tornou-se raro; contudo, ele ainda se faz presente em projetos artísticos e educativos específicos.

A crise da banalização da fotografia em decorrência de sua onipresença na nossa vida cotidiana e na cultura visual que vivemos hoje, junto à proliferação e facilidade de criação de imagens decorrente da sofisticação e facilidade de uso das câmeras em smartphones e de aplicativos de trocas e tratamento de imagens, já era assinalada por Vilém Flusser há mais de 30 anos:

Fotografias são onipresentes: coladas em álbuns, reproduzidas em jornais, expostas em vitrines, paredes de escritórios, afixadas contra muros sob forma de cartazes, impressas em livros, latas de conservas, camisetas. [...] Vistas ingenuamente, significam cenas que se imprimiram automaticamente sobre superfícies (FLUSSER, 2009, p. 22).

Hoje, fazer fotografias se tornou algo tão fácil e banal que sequer as olhamos novamente e mal conseguimos organizar as imagens feitas. Em contraposição a essa banalização e velocidade de produção de imagens e dialogando com a história dá fotografia, Dirceu Maués, um dos artistas participantes da mostra, com ampla trajetória na experimentação com câmeras artesanais sem lentes, escreve sobre o seu processo de construção e intervenção nos mecanismos produtores de imagens:

Construir seu próprio dispositivo para criar imagens da forma mais simples e mais básica, partindo do princípio da câmera obscura para fabricar uma câmera pinhole - essa simples caixa preta com um pequeno orifício em um de seus lados a projetar a imagem do mundo exterior na parede interna. Sem visor de enquadramento, sem botão disparador, sem lentes. Onde o tempo é degelo e não congelamento. Uma lógica um tanto diferente da lógica que regeu a fotografia moderna, a fotografia do instantâneo e da precisão da imagem. Construir o próprio dispositivo, 


\section{Dossiê Fotografia, Arte e História \\ na atualidade: relações praticadas}

portanto, dialogando com o pensamento de Certeau, é uma forma de escapar da programação imposta por toda uma ordem que envolve a fotografia e que acompanha a câmera fotográfica como objeto industrial (MAUÉS, 2015, p. 13).

E completa:

Construir o próprio dispositivo, nesse sentido, faz parte das ações táticas: é se aproveitar de toda estrutura que ainda envolve a fotografia, seja analógica ou digital, para fugir de um certo padrão de uso da técnica e da linguagem fotográfica, ao mesmo tempo em que expande o campo de atuação da linguagem para um lugar de fronteira com outras linguagens, como o vídeo, o cinema, a instalação e a intervenção urbana (MAUÉS, 2015, p. 14).

Os conceitos de dispositivo ${ }^{4}$, de Agamben (2009), e de aparelho5 ${ }^{5}$, de Vilém Flusser (2009), aparecem com frequência nos escritos e referências dos artistas e pensadores que buscam refletir sobre obras e processos que envolvem a produção de imagens por meio da câmera obscura e de câmeras artesanais. À luz das questões e inquietações já levantadas, a seguir serão descritas e analisadas as obras dos artistas participantes do eixo curatorial Imagem Mágica.

\section{Experimentos com a cầmera obscura em obras instalativas: Dirceu Maués e suas (In)versões na paisagem}

A obra (In)versões na paisagem (Imagem 3) foi construída ao longo de quatro dias, dentro da oficina de mesmo nome, com auxílio dos alunos inscritos. Sessenta tambores azuis de 200 litros formaram duas estruturas triangulares nas duas extremidades da plataforma da Estação Cultura, antiga estação ferroviária da cidade de Campinas, transformada em espaço cultural pela Prefeitura de Campinas, em 2002, onde acontecem diversos eventos ao longo do ano. Cada um dos tambores teve seu interior pintado de preto e foi transformado em uma câmera escura de visualização através da instalação de um orifício com lente em uma das extremidades e de um anteparo de papel vegetal

4 Agamben (2009, p. 40-41), em seu artigo O que é um dispositivo?, assim o define: "Ceneralizando posteriormente a já bastate ampla classe dos dispositivos foucaultianos, chamarei literalmente de dispositivo qualquer coisa que tenha de algum modo a capacidade de capturar, orientar, determinar, interceptar, modelar, controlar e assegurar os gestos, as condutas, as opiniões e os discursos dos seres viventes. Não somente, portanto, as prisões, os manicômios, o Panóptico, as escolas, a confissão, as fábricas, as disciplinas, as medidas jurídicas, etc., cuja conexão com o poder é num certo sentido evidente, mas também a caneta, a escritura, a literatura, a filosofia, a agricultúra, o cigarro, a navegação, os computadores, os telefones celulares e-por que não-a própria linguagem, que talvez é o mais antigo dos dispositivos, em que há milhares e milhares de anos um primataprovavelmente sem se dar conta das consequências que se seguiriam - teve a inconsciência de se deixar capturar". 5 Vilém Flusser (1985, p. 5) define "aparelho", no glossário de Filosofia da Caixa Preta, como "brinquedo que simula um tipo de pensamento" e 'aparelho fotográfico' como "brinquedo que traduz pensamento conceitual em fotografia". 
sustentado por um aro de Eucatex no meio. A outra extremidade (onde seria colocada a tampa) permaneceu aberta, permitindo aos passantes a visualização da imagem invertida do que acontecia do outro lado da instalação. Uma espécie de "cinema ao vivo" que causou espanto aos transeuntes pela "mágica" e pela simplicidade do dispositivo. Nas palavras do artista:

Esse encantamento com a imagem 'mágica' e intrigante que se projeta invertida no interior da câmera escura parece estar relacionado à nossa crença de que apenas os dispositivos tecnológicos, considerados altamente complexos, são capazes de produzir imagens surpreendentes. Há, portanto, uma certa incredulidade com processos tecnológicos mais simples ou precários. E é justamente dessa incredulidade que surge o espanto. Neste sentido, vivenciar a experiência da câmera escura em um encontro casual na cidade provoca nesse espectador-transeunte certos deslocamentos (MAUÉS, 2015, p. 77).

A imagem dentro da câmera escura, efêmera e em movimento, mostra o mundo de ponta-cabeça e com os lados invertidos. As reflexões feitas pelo artista a respeito da obra Horizonte reverso, cuja pesquisa precede In-versões na paisagem, também se encaixam nesse contexto:

Horizonte reverso convida o espectador a brincar com o dispositivo, a descobrir seu funcionamento, a des-

Imagem 3 - Vista da instalação (In)versões na paisagem em uma das extremidades da plataforma da Estação Cultura (2017).

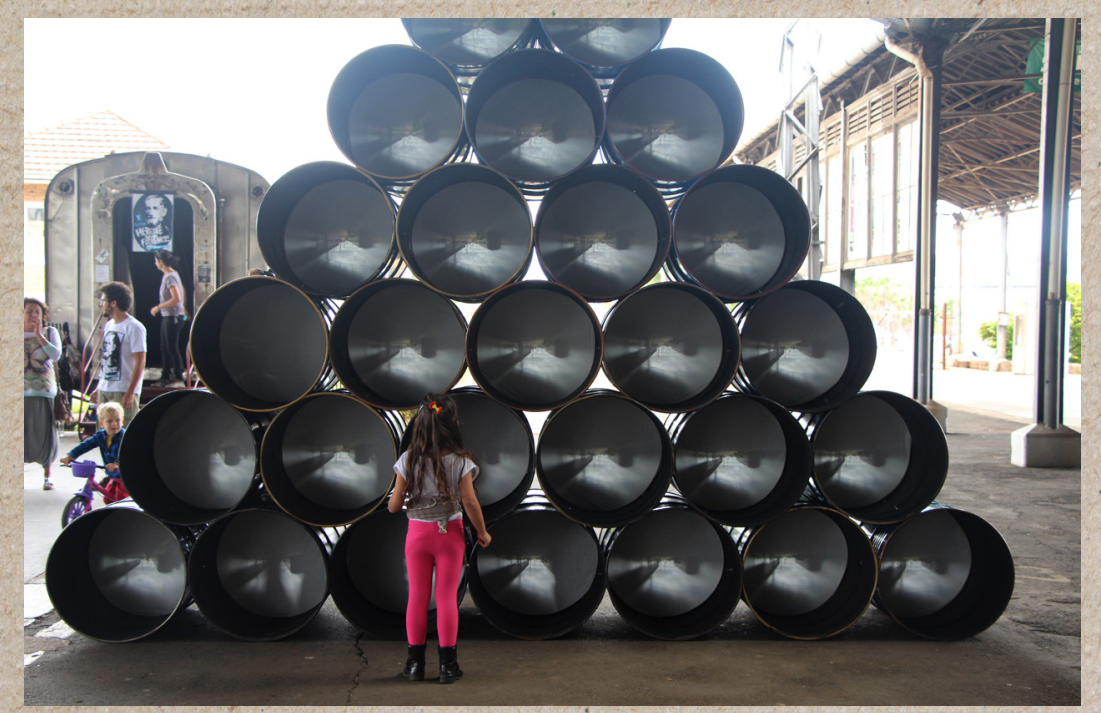

Fonte: Elaborada pela autora. vendar os segredos da 'caixa preta' de Flusser. Há um certo espanto na reação do público ao (re)descobrir a simplicidade que se esconde por trás do funcionamento de alguns dispositivos tecnológicos complexos, ao descobrir que aquela imagem tão colorida e encantadora dentro das simples caixas de papelão não envolve nenhuma tecnologia complexa. Esse espanto revela muito sobre o quanto nos afastamos de uma compreensão crítica sobre os objetos tecnológicos que nos cercam, em nosso cotidiano (MAUÉS, 2015, p. 79-80).

Autor de obras que misturam a captação de imagens feitas por meio de equipamentos precários, como câmeras de madeira ou feitas a partir de caixinhas de fósforo, à edição de vídeo digi- 


\section{Dossiê

tal e vídeo instalações com múltiplos canais, Maués mescla uma simplicidade de meios com a complexidade no modo de operar seus dispositivos. Em uma de suas primeiras obras a chamar a atenção da crítica especializada - ... feito poeira ao vento... -, utilizou 38 câmeras para fazer 991 fotografias em $360^{\circ}$ ao longo de um dia, no Mercado Ver-o-peso, em Belém do Pará. Para conseguir essas imagens, Dirceu elaborou um mecanismo para melhor controlar a exposição das imagens em $360^{\circ}$, dividindo o número de fotos durante o dia, de forma a registrar esse movimento ao longo do tempo e do espaço com certa uniformidade. Criou, ainda, uma forma de operar as câmeras para prevenir novas exposições de filmes já expostos.

Segundo o artista, a expansão do seu trabalho para o campo da arte acontece a partir do aprofundamento da sua pesquisa artística no interior do dispositivo fotográfico (MAUÉS, 2015, p. 51). Ao mesmo tempo em que escolhe trabalhar com uma câmera pinhole, um dos dispositivos mais simples de produção de imagens, a complexidade no seu modo de operar se revela na construção de engenhocas para as tomadas das fotos e na posterior remontagem das imagens em forma de vídeo, instalação etc. Em suas palavras:

A fotografia pinhole, portanto, se insere no conceito de campo expandido da fotografia: uma produção de imagens que parte de uma revisitação a parâmetros e técnicas esquecidas pelo desenvolvimento tecnológico. Essa revisitação se torna uma grande oportunidade de experimentar mais a fundo a própria linguagem fotográfica e suas possibilidades de imbricações com outros campos, pensando que cada inovação tecnológica é mais uma ferramenta dentro do campo de possibilidades de criação do artista a agregar novas potencialidades a técnicas e procedimentos anteriores e (ou) vice-versa (MAUÉS, 2015, p. 22).

\section{Experimentos com a forma e a deformação da imágem: as anamorfoses de Luiz Alberto Guimarães}

Luiz Alberto Guimarães é físico de formação e a sua entrada no circuito da fotografia carioca se deu de forma um tanto surpreendente. Professor e escritor de livros de física para o ensino médio, o artista encontrou na fotografia, mais precisamente na fotografia feita com câmeras artesanais, uma forma de recompor a vida após uma crise de transtorno de ansiedade. Foi assim que produziu Retratos do Indizivel (2007-2008) - uma série de autorretratos que, segundo o também fotógrafo e historiador Pedro Vasquez (2014, p. 193), 
se inscreve entre o que há de melhor no gênero no Brasil. Um trabalho brilhante, impressionante, visceral, pessoal e profundamente tocante, capaz de exercer um efeito tran'sformador na vida do observador sensível, equivalente ao produzido na própria vida do autor.

Pelo fato de ser físico, o artista compreende com facilidade o funcionamento da projeção da luz, construindo câmeras altamente complexas com diversas entradas de luz e diferentes planos para a captação das imagens. Para Cúba Libre, série apresentada na exposição Imagem Mágica, o fotógrafo transformou uma caixa de charutos cubanos em câmera fotográfica a partir da inserção de quatro entradas de luz, uma em cada face lateral da caixa, e posicionou o papel fotográfico na sua base, em posição perpendicular às entradas de luz. As imagens geradas são anamórficas (pela posição do papel) e sobrepostas (pela multiplicidade de "furos") e são consideradas 'imagens cegas', pelo fato de a câmera não possuir visor e pela dificuldade de previsão do que será impresso no papel fotográfico mediante tais condições. Como afirma Luciano Laner, fotógrafo gaúcho também praticante da fotografia feita com câmeras pinhole artesanais:

Percebe-se, então, que a fotografia pinhole permite outra interpretação do ato fotográfico, no que diz respeito às tensões e diferenças entre a visão do fotógrafo e a visualidade produzida pela câmera obscura fotográfica. Com a substituição das objetivas pelo pinhole e com a supressão dos sistemas de espelhos e do visualizador funcional que permitem ao fotógrafo 'enxergar' o que a câmera 'vê', a fotografia pinhole passa a ser, para o fotógrafo, uma fotografia 'às cegas' que desenvolve a visão autônoma do aparelho. Assim, a influência do fotógrafo sobre o processo de produção da imagem, principalmente no que diz respeito ao enquadramento, passa da indução ao diálogo. A indução do aparelho corresponde ao imaginário fotográfico trazido pelo fotógrafo é, portanto, uma visão fotográfica antecipada e influenciada pelo imaginário fotográfico. Pode-se dizer que a indução é portadora do desejo de imagem do fotógrafo, que trabaIha para impor ao aparelho o seu imaginário e o seu plano, quase sempre existentes como imagem latente, mesmo antes da captura (LANER, 2014, p. 64).

Imagem 4-Esquema da câmera utilizada na série Cuba Libre, de Luiz Alberto Guimarães (2015).

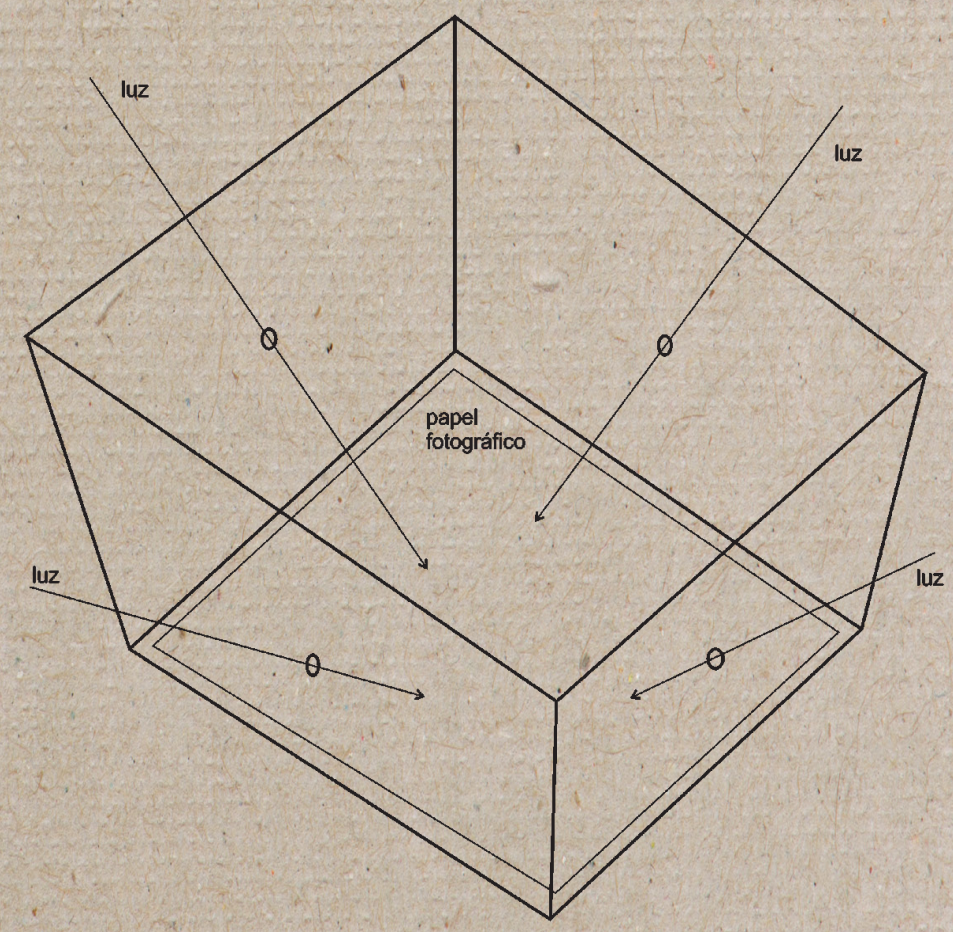

Fonte: Guimarães (2015). 
Assim, o papel do fotógrafo, aqui, assemelha-se mais ao de um projetista: idealiza e constrói sua câmera a partir de uma ideia inicial que pode se originar do próprio formato do objeto que pretende transformar em câmera ou do que pretende retratar. Aproxima-se, ainda, de um orquestrador de acasos, uma vez que a ampliação do tempo de exposição à luz pela ausência de lentes e a ausência de visor tornam o resultado da imagem um tanto imprevisível. Isso sem falar nas projeções anamórficas e superposições de imagens no interior da câmera.

Imagem 5-Câmera utilizada na série Cuba Libre, de Luiz Alberto Guimarães (2015). $60 \times 60 \mathrm{~cm}$.

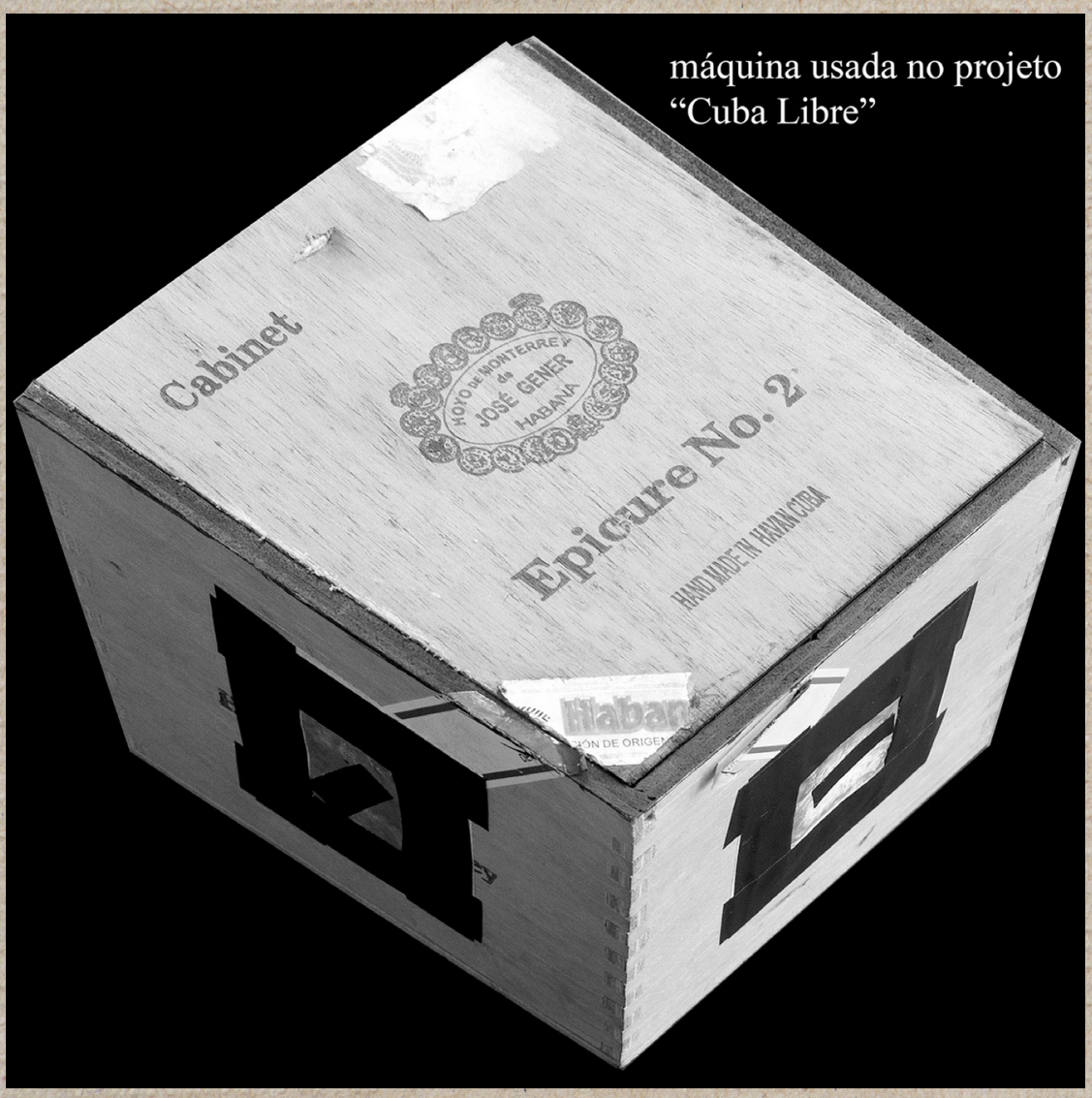

Fonte: Guimarães (2015)
Não considero as máquinas artesanais cópias toscas das máquinas fotográficas industriais, mas sim aparelhos destinados a produzir imagens que 0 programa destas últimas não está habilitado a fornecer, ou que só poderiam ser obtidas através de manipulações digitais sofisticadas. Apesar de o nível de manipulação propiciado pelo Photoshop e outros produtos de software permitir, em princípio, qualquer resultado (certamente, Flusser diria nos dias de hoje que, como máquina suprema, o computador tem seu universo de realizações muito próximo do infinito), essa possibilidade não substitui a aura - num sentido próximo ao que Ihe dá Walter Benjamin - que envolve um instrumento artesanal único, e a magia de conseguir produzir, com caixas de papelão sem lentes, uma linguagem visual sofisticada e complexa (talvez eu deva dizer que uso máquinas artesanais para poder ver meus sonhos e pesadelos, deixando para os olhos a ilusão de ver o real...). Utilizo-as quase sempre para subverter os conceitos de tempo e espaço tão caros à forma fotografia. Por exemplo: se para os pioneiros da fotografia o longo tempo de exposição era um problema a ser resolvido, muitas vezes para mim ele se transforma em solução. Em um dos projetos que realizei, de autorretratos, esse tempo chegou a atingir 8 minutos. Em outro, no qual queria criar um estranhamento nas paisagens urbanas, fotografei vias importantes, em horário de grande movimento, e só pude obter o resultado desejado por conta de uma exposição da 
ordem de 2 minutos [...]. Pude assim ultrapassar os códigos da chamada caixa preta da fotografia, conseguindo produzir cenas provavelmente irrealizáveis com uma máquina convencional (CUIMARÃES, 2014, p. 22).

Imagem 6 - Imagem da série Cuba Libre, de Luiz Alberto Guimarães (2015). $[60 \times 60 \mathrm{~cm}]$.

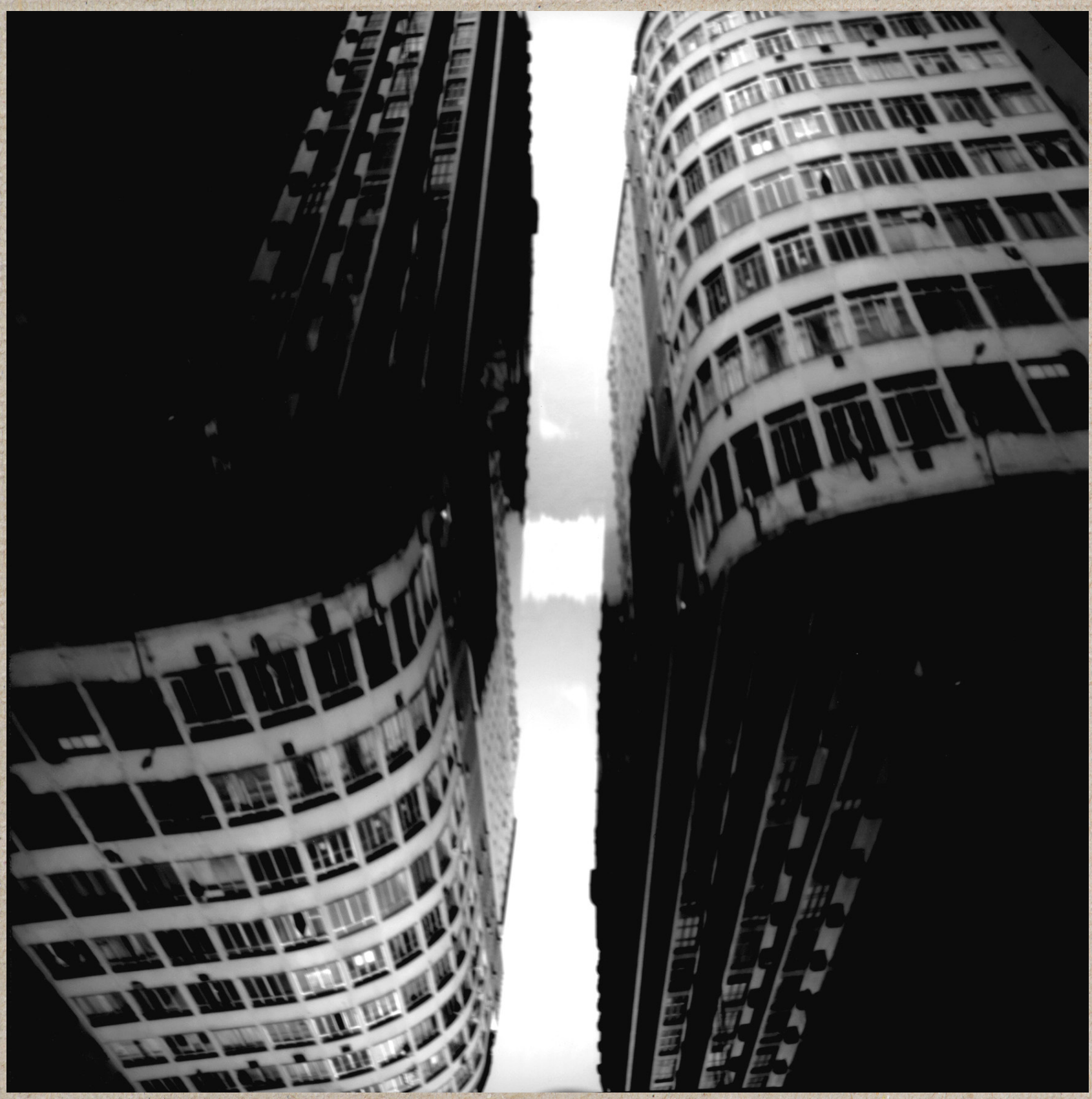

Fonte: Luiz Alberto Guimarães (acervo pessoal).

Desta forma, Luiz Alberto constrói suas máquinas com a destreza de um físico de formação a fim de subverter - em seu processo e em suas imagens - as práticas da fotografia vernaculare as limitações impostas pelo mercado às câmeras industriais, sejam digitais ou analógicas. 


\section{Dossiê

\section{Experimentos com o tempo: os panoramas Imaginários de Mônica Mansur}

Os Panoramas imaginários de Mônica Mạnsur são imagens feitas com uma câmera Agfa-Gevaert' de baquelite, que utiliza filme formato $120 \mathrm{~mm}$, transformada em pinhole. A câmera teve suas lentes retiradas e em seu lugar foi colocada uma placa dè metal com um furo menor do que uma cabeça de alfinete. Ao fotografar, Mônica Mansur produz uma imagem contínua - derivada de uma série de tomadas que se superpõem - que abrange o filme por inteiro. Montadas de forma circular em cima de uma base preta quadrada, essas imagens-objetos remontam à forma dos panoramas tão populares no século XIX, só que em escala reduzida: se em 1800 o público "entrava" no panorama em uma experiência quase imersiva, os Panoramas Imaginários de Mônica Mansur são vistos de cima e de uma só vez: podemos circular em torno deles, mas não em seu interior. Sobre a série, a artista escreve:

Em minha série Panoramas Imaginários, fotografias captadas por uma pinhole em filme 120, 0 negativo recebe por inteiro a imagem trazida pela luz, mediante várias exposições que acontecem durante o deambular do fotógrafo. As imagens não são panoramas verdadeiros, são as possibilidades imaginárias do olhar a passeio, são imagens cristais, imagens em si, não paisagens; são afirmações do significado de paisagem como imagem e como conceito. São o ir e vir, a sobreposição, a dupla exposição, a inclinação. São a construção de uma paisagem inexistente, inventada; impressões, imitações, ficção. São imagens de um tempo sobreposto, composto, paradoxal e recuperado, passeio num tempo indefinido, volta ao passado e imersão no futuro'.. (MANSUR; 2014, p. 212).

Imagem 7 - Panorama Imaginário, de Monica Mansur (2014).

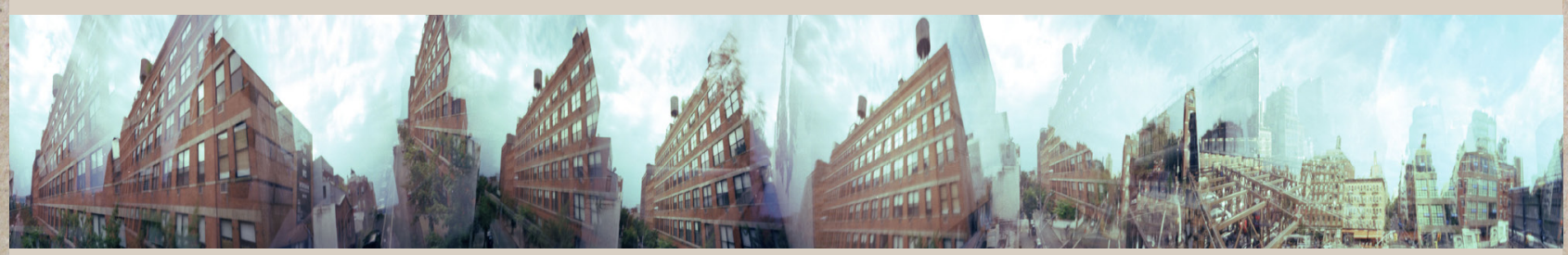

Fonte: Acervo pessoal de Monica Mansur

Imagem utilizada na série "Panoramas imaginários", exposta de forma circular em cima de uma base preta quadrada.

O panorama, escreve Phillipe Dubois (1998), é como um plano de cinema realizado em fotografia. Especialmente nos panoramas de Monica Mansur acontece uma multiplicação de perspectivas: 
Mesmo se foi tirada de uma só vez e a partir de um lugar único, a foto panorâmica, pela rotação da tomada, desdobra-se em várias perspectivas que fogem em direções diferentes.' Teoricamente, há tantas perspectivas que existem raios no decorrer da rotação. [...] Não se pode, verdadeiramente, ler nele as horas, e sim o espaço percorrido; não exatamente o tempo em si, mas o, movimento (da rotação) (DUBOIS, 1998, p. 226).

Aíse estabelece a ligação com o cinematógrafo, mesmo a imagem sendo fotográfica, pois a relação com o tempo no panorama fotográfico ocorre por meio da captura de instantes progressiva e continuamente, ao se deslocar no espaço. É o movimento durante a tomada, o deambular do fotógrafo. Nos Panoramas Imaginários de Mansur, a superfície do filme não é impressa de uma só vez, mas a partir do deslocamento no tempo e no espaço da artista, ao fotografar, e do filme dentro da câmera. O tempo fica inscrito no filme e na imagem, e o momento do seu início difere do final.

O mesmo acontece com o espectador ao contemplar o panorama: o olho deve percorrê-lo mediante um deslocamento no espaço, em um período de tempo. O panorama representa várias vezes a mesma coisa em momentos diferentes. É, como descreve Dubois (1998, p. 229), "o cinema na foto, [...] um espaço que se percorre e uma duração que se faz sentir".

Os panoramas de Mansur, no entanto, ainda apresentam uma diferença: sua imagem é impressa diretamente no filme, sem mediação de lentes objetivas. Todo o processo de deambular da artista ao fotografar aparece na imagem final. Em suas palavras:

Em minha fotografia capturada em câmera escura, através de um buraco de agulha, tudo a respeito da formação da imagem aparece no resultado final: a forma como a luz carrega a imagem para depositá-la na superfície fotossensível, sem intermediações ou correções, em processo análogo à forma como o olho recebe o corpo de informações visuais que irá se compor no cérebro e determinar um objeto imaginário (MANSUR, .2014, p. 213).

Imagem 8 - Panorama Imaginário, de Monica Mansur (2014).

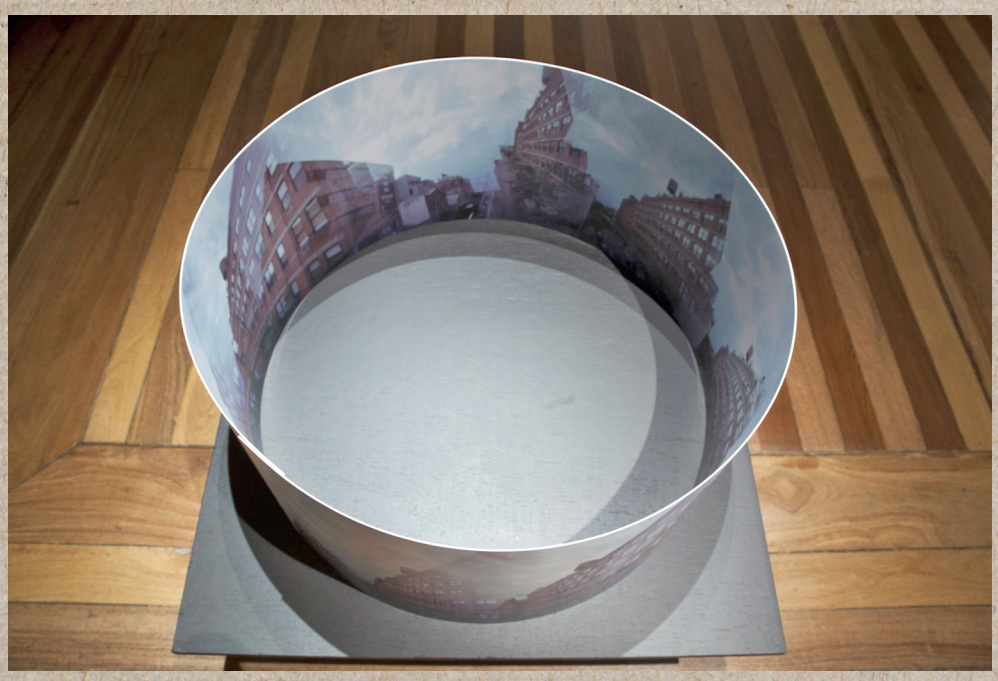

Fonte: Monica Mansur (acervo pessoal).

Fotografia impressa digitalmente em papel de algodão, montada em puc sobre base quadrada de madeira. 
Diferente dos panoramas do século XIX, nos Panoramas Imaginários de Mônica Mansur o espectador não fica no centro, mas o contorna. Ainda assim, sua percepção é sucessiva, desenrola-se no tempo, pois o público não o apreende de uma só vez: é preciso deslocar-se, contorná-lo, olhar por dentro e por fora e em diálogo com o ambiente.

\section{Processos colaborativos em projetos educativos e sociais realizando obras coletivas: Urublues, de Miguel Chikaoka}

Miguel Chikaoka explora a potência pedagógica dos processos fotográficos de captura da imagem e impressão fotoquímica no papel para além da formação técnica na área da fotografia. Considera os "fazeres" como ativadores de experiências sensoriais. Engenheiro eletricista de formação, descobriu a prática da fotografia na França, onde cursava o doutorado na Escola Superior de Engenharia, em Nancy, no final da década de 1970. Paralelamente às atividades acadêmicas, participou do Photo Club de Monbois-Boudonville, onde frequentava o laboratório de fotografia; nessa época, despertaram sua atenção autores como David Cooper, Ronald Laing, Raul Vaneigem, Paulo Freire e Augusto Boal. Voltando ao Brasil, abandonou a Engenharia e mudou-se para Belém, onde vive até hoje. Lá, iniciou o trabalho como fotógrafo independente e foi convidado a ministrar o primeiro curso de iniciação à fotografia. Sobre esse momento, o artista escreve:

Comecei, intuitivamente, mesclando o repertório de pensamentos que absorvi nas leituras com uma visão panorâmica do meu processo de aprendizado, e desenhei um percurso tendo como norte facilitar o entendimento da fotografia a partir do reconhecimento da luz como matriz do processo. Ou seja, entender que, não importa a marca, modelo e tamanho' da câmera, o princípio da formação e captura da imagem se processam pela e com a natureza da luz, chamando atenção para o que acontece no nosso olho. Ou seja, sugerir que a prática da fotografia, como soma e congelamento de um lapso de tempo e de um campo da nossa visão, real ou imaginário, poderia representar o exercício do nosso olhar, do nosso pensamento e, portanto, a expressão do nosso estado de ser, estar ou pensar. De todo modo, nas minhas incursões como facilitador, os exercícios eram realizados com uso de câmeras convencionais, possuindo dispositivos de leitura e controles de luz mais ou menos sofisticados (CHIKAOKA, 2014, p. 129).

Descendente de família de origem japonesa, Chikaoka traz muito dessa cultura em suas práticas e reflexões: suas oficinas são verdadeiras vivências (Imagem 9) não apenas em torno da experimentação com a luz e com o fenômeno da formação da imagem, mas ao provocar profundás reflexões acerca da forma como vivemos e de como utilizamos os recursos disponíveis, 
sempre relacionando o micro (o pequeno furo da câmera feito com espinho de uma árvore amazônica) ao macro (as distâncias percorridas pela luz), o exterior (as atividadés propostas) ao interior (o que elas significam para os participantes), ressaltando, ainda, o caráter místico e simbólico que a luz possui em quase todas as culturas e religiões.

Sobre as imagens feitas com câmeras pinhole, reflete:

O lugar do furo da agulha, ou do espinho, foi um lugar de inspiração para pensar o todo a partir de um ponto. Ponto de convergência dos raios de luz. Onde aprendi que menos pode ser mais. Que posso exercitar o que inspira o pensamento de uma música da banda Titãs: uma coisa de cada vez, tudo ao mesmo tempo agora. Sim, porque a potência desse processo está na luz. Essa luz que se espalha e nos leva a dimensões que podemos imaginar, mas só podemos experimentar fisicamente com alguns dos nossos sentidos, como o da visão. Estar com a luz e aprender com ela é estar de acordo com as leis do universo. Luz-fogo, elemento vital que tem seus pares, como a água, a terra e o ar. Penso que a educação do presente, se quisermos um futuro, precisa de um realinhamento com a potência pedagógica desses elementos (CHIKAOKA, 2014, p. 138).

Em consonância com o seu percurso, a atuação de Chikaoka no $10^{\circ}$ Festival Hercule Florence de Fotografia de Campinas teve início cerca de vinte dias antes das outras atividades do Festival com um processo de envolvimento sensível para as potencialidades da imagem fotográfica por meio da oficina/vivência Fototaxia: Em busca do elo perdido (Imagem 10). Nela foram utilizados pedaços de tecido para vendar os olhos, sementes guardadas num saco, pequenos pedaços de papel fotográfico, revelador utilizado Imagem 9-O furo do espinho na oficina Fototaxia-Em busca do elo perdido (2017). como tinta, além dos já tradicionais materiais comuns em diversos cursos de fotografia analógica ou de fotografia com câmeras artesanais. Sua oficina foi uma vivência em torno do fotográfico e do lugar das imagens no imaginário e na vida dos participantes.

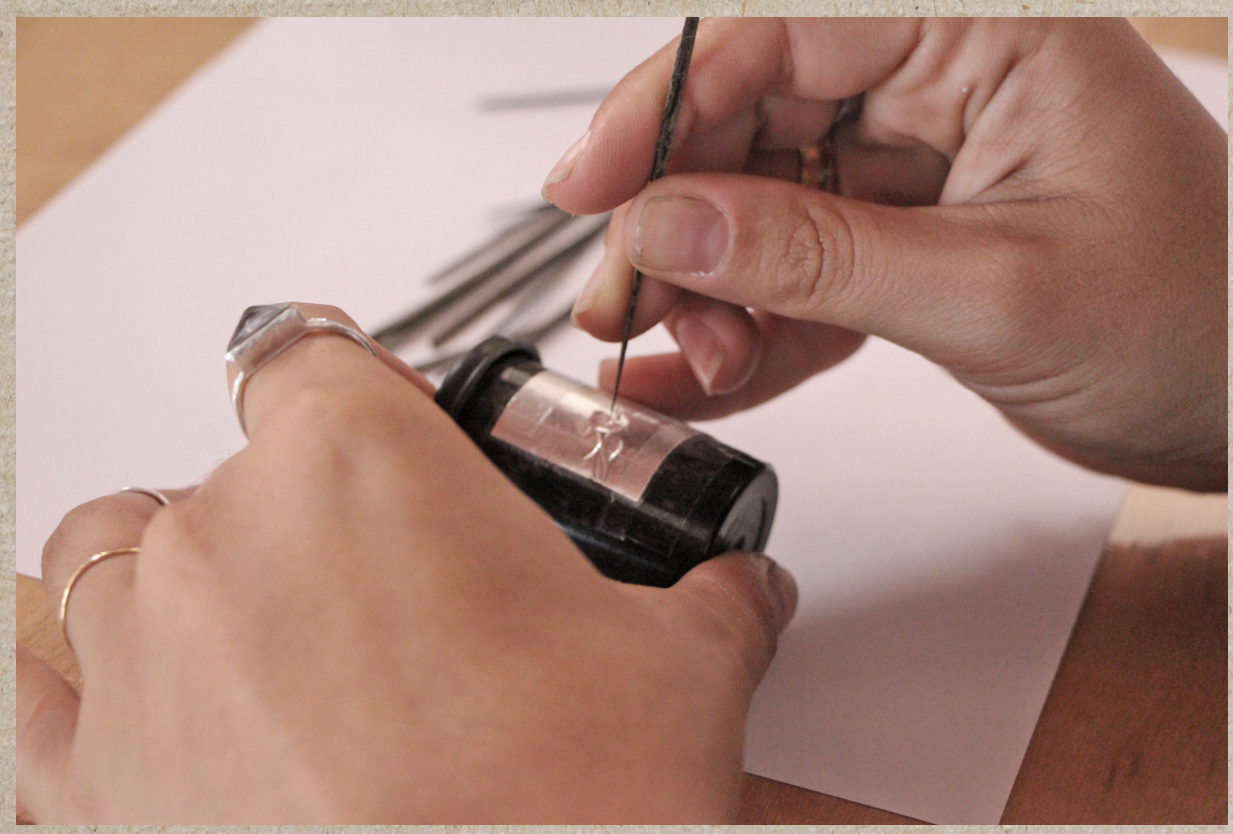

Fonte: Elaborada pela autora. 
O objetivo final de sua participação no Festival era a realização do painel Urublues Campinas, que teve como origem outro painel de mesmo nome criado a partir de um convite para o $\mathrm{Me}$ morial dos Povos de Belém do Pará. O Urublues, de Belém, era um painel-mosaico constituído por 8 mil foto-pixels (imagens do mercado Ver-o-Peso capturadas em papel fotográfico com câmeras pinhole feitas com tubinhos de filme). Esse painel inicial foi inteiramente montado de forma analógica, com separação das imagens por escalas de cinza.

\section{Imagem 10-Documentação da oficina Fototaxia - Em busca do elo perdido (2017).}

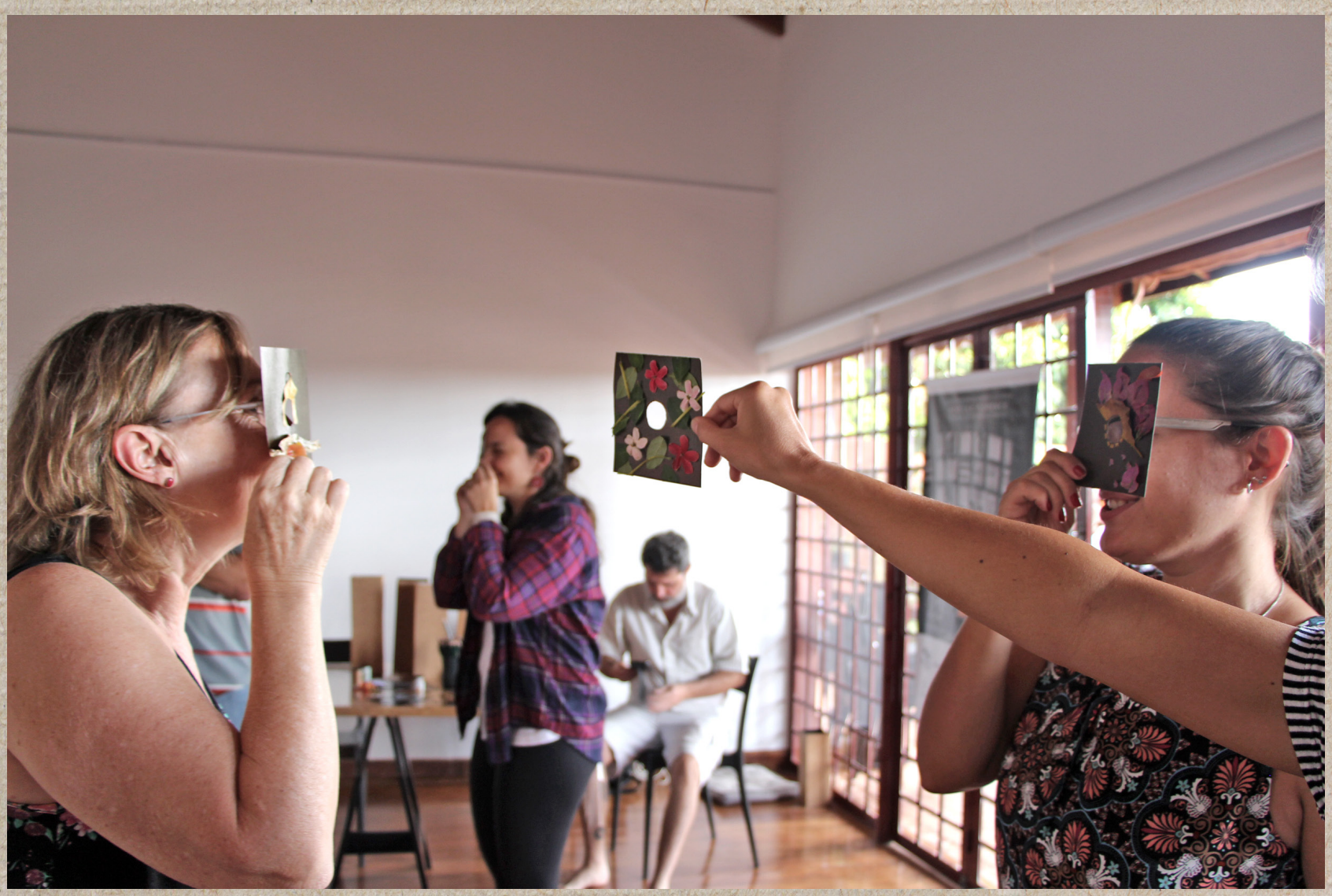

Fonte: Elaborada pela autora.

Para o Urublues Campinas, por sua vez, o artista contou com o auxílio de um software de gerenciamento de imagens que gerou digitalmente a imagem impressa, formada por 19 mil foto-pixels derivadas de 2 mil imagens feitas com tubinhos de filme. Ao longo de dez dias, foi montado um laboratório, dentro de um vagão de trem desativado e aberto ao público, que funcionou cerca de 8 horas por dia. Mais de 200 pessoas passaram pelo vagão e fizeram ao menos uma foto. Depois as imagens foram scaneadas, arquivadas em um banco de imagens e transformadas no painel, com ajuda do software Foto Mosaik-Edda (2017). A imagem-matriz-também feita com câmera pinhole - foi uma imagem panorâmica, feita pelo próprio artista durante a sua estadia em Campinas, retratando a Estação Cultura (Imagem 11). 
Imagem 11 - Urublues Campinas (2017), de Miguel Chikaoka.

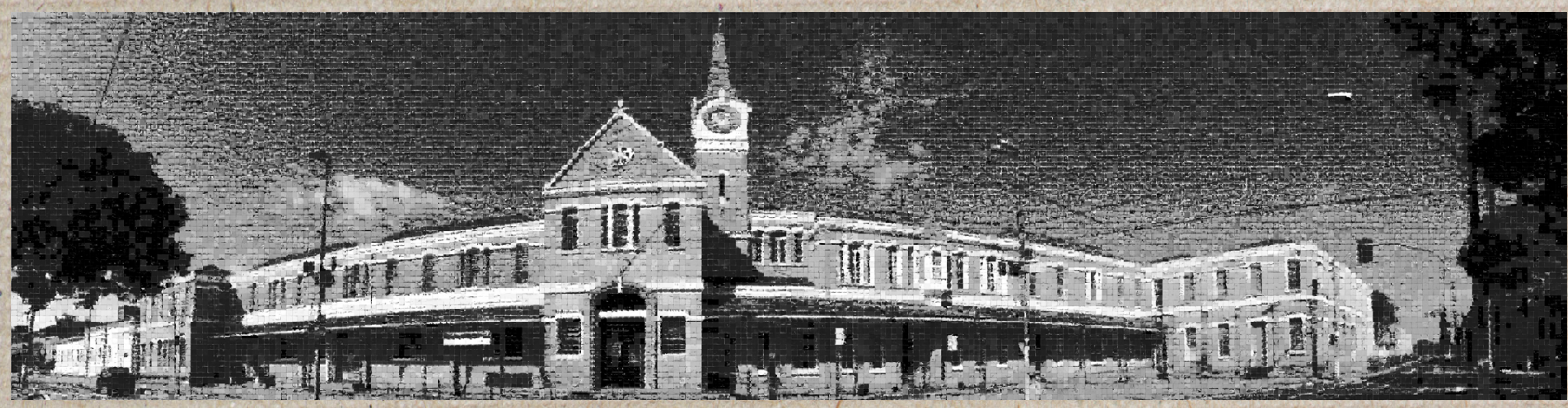

Fonte: Miguel Chikaoka (acervo pessoal).

\section{Considerações finais}

De fato, a contemporaneidade se escreve no presente assinalando-o antes de tudo como arcaico, e somente quem percebe no mais moderno e recente os índices e as assinaturas do arcaico pode dele ser contemporâneo. Arcaico significa: próximo da arké, isto é, da origem. Mas a origem não está situada apenas num passado cronológico: ela é contemporânea ao devir histórico e não cessa de operar neste, como o embrião continua a agir nos tecidos do organismo maduro e a criança na vida psíquica do adulto (AGAMBEN, 2009, p. 69).

Um observador atento às cenas da fotografia e da arte contemporânea brasileiras certamente teve a oportunidade de notar a presença expressiva de obras que retomam o dispositivo da câmera obscura e as formas artesanais de produção de imagens, em exposições em museus e galerias de arte. O eixo curatorial Imagem Mágica, dentro do $10^{\circ} \mathrm{Festival} \mathrm{Hercule} \mathrm{Florence} \mathrm{de} \mathrm{Foto-}$ grafia, e este artigo pretendem levantar algumas questões acerca do significado dessa retomada da origem da fotografia e dos modos artesanais de produção de imagenș no atual contexto da cultura digital contemporânea. Experimentar a câmera obscura, hoje, em muito difere da experiência do sujeito do século XVIII. Como afirmam Antônio Fatorelli e Victa de Carvalho (2014, p. 48):

Surpreende observar a maneira pela qual as transformações processadas atualmente no interior da prática fotográfica deslocam a natureza e o destino das imagens, ao mesmo tempo que reordenam os modos pelos quais àcessamos os formatos históricos de produção imagética. É o conjunto da prática fotográfica que se encontra redimensionado pelo olhar atual, desde as experimentações com os suportes materiais, predominante no período anterior à estandardização generalizada dos procedimentos e dos equipamentos fotográficos - com destaque para as práticas intervencionistas que singularizaram os pictorialistas no século XIX-, e as experimentações com a fotografia das vanguardas históricas. 


\section{Dossiê

De forma diferente das considerações de Jonathan Crary (2012) acerca da descontinuidade do modelo da câmera escura e o surgimento da fotografia ${ }^{6}$, nestas experiências contemporâneas o corpo desempenha um papel decisivo, destacando o caráter extemporâneo (no sentido de além do seu tempo) da câmera obscura:

A câmera escura apresenta-se, na atualidade, como uma tecnologia imagética enraizada de tal modo na presença corporal, nas formações híbridas e no tempo multivetorial que é capaz de promover a revisão das conviç̧ões habitualmente associadas à fotografia, no duplo sentido de subverter o modo como a câmera escura foi mobilizada no século XVIII e de problematizar um discurso corrente sobre a cultura digital, fundamentado na pulverização dos suportes físicos da imagem e na perda da experiência corporal. Portanto, como um dispositivo anacrônico, capaz de desempenhar funções variáveis em diferentes conjunturas, que coloca simultaneamente em perspectiva os regimes pré e pós-fotográficos (FATORELLI \& CARVALHO, 2014, p. 53).

\section{E continuam:}

Ao reforçar as relações entre a imagem e o mundo, os procedimentos da câmera escura confrontam-se abertamente com a intenção de transparência, preponderante no regime clássico, ao mesmo tempo que se distanciam das concepções de natureza abstrata, frequentemente associadas às tecnologias digitais. De modo radicalmente diverso, a confirmação do vínculo indicial, sancionada pela câmera escura, designa uma modalidade de experiência estética processada na presença dos objetos e fenômenos do mundo, em vista de um observador mais plástico e maleável, e de um corpo produtor de diferenças, decisivamente implicado no processo de produção da imagem (FATORELLI \& CARVALHO, 2014, p. 53).

Assim, podemos entender que tanto as experimentações com câmeraș escuras como as experimentações com suportes materiais e técnicas alternativas de produção de imagens envolvem, após o advento e disseminação da cultura digital, um retorno corporal do vínculo com o fazer como processo constitutivo da obra, seja em forma de instal lação ou imagem.

6 Jonathan Crary, em seu livro Técnicas do observador -Visão e modernidade no século XIX (2012), diferente do que costumam ensinar os manuais de fotografia, defende a existência de uma descontinuidade entre a posição do sujeito que utilizava a câmera obscura no século XVIII e o sujeito que utilizava a câmera fotográfica no século XIX. Apesar de ambos utilizarem o mesmo princípio ótico da camera escura, a posição do observadorem muito difere nesses dois modelos de produção de conhecimento: enquanto no primeiro um observador incorpóreo encontra-se apartado do mundo, no segundo o envolvimento corpóreo do observador na experiência visual contribui para torná-la uma experiência subjetiva. 


\section{Referências}

ACAMBEN, Giorgio. O que é o contemporâneo? E outros ensaios. Tradução de Vinicius Nicastro Honesko. Chapecó: Argos, 2009.

BRESSANE, Júlio. Alguns. Rio de Janeiro: Imago, 1996.

CHIKAOKA, Miguel. Pinholeando (ou mottai-nai) potências e possibilidades pedagógicas dos fazeres. In: COSTA, Ana Angélica. Possibilidades da câmera obscura. Rio de Janeiro: Projeto Subsolo; Funarte; SMC$-R], 2014$.

CRARY, Jonathan. Técnicas do observador: visão e modernidade no século XIX. Tradução de Verrah Chamma. Rio de Janeiro: Contraponto, 2012.

DUBOIS, Phillipe. A fotografia panorâmica ou quando a imagem fixa faz sua encenação. In: SAMAIN, Etienne (Org.). O fotográfico. São Paulo: Hutitec, 1998.

FATORELLI, Antônio. Modalidades de inscrição temporal nas imagens fotográficas. In: FATORELLI,Antônio; CARVALHO, Victa de; PIMENTEL, Leandro (Orgs.). Fotografia contemporânea: desafios e tendências. Rio de Janeiro: MauadX, 2016.

FATORELLI, Antônio; CARVALHO, Victa de. A câmera escura na Fotografia Brasileira Contemporânea. In: COSTA, Ana Angélica (Org.). Possibilidades da câmera obscura. Rio de Janeiro: Projeto Subsolo; Funarte; SMC-R], 2014.

FLUSSER, Vilém. Filosofia da caixa preta: por uma futura filosofia da fotografia. Rio de Janeiro: Relume Dumará, 2009. (Coleção Conexões).

FOTO MOSAIK - Edda [software]. 2017. Disponível em: <https://fmedda.com/en>. Acesso em: 20 jan. 2018.

GUIMARÃES, Luiz Alberto. Essas máquinas maravilhosas: uma proposta de diálogo entre artesania e tecnologia, através das máquinas fotográficas pinhole, numa tentativa de reconciliação da ciência com a magia. Trabalho de Conclusão de Curso (Pós-Graduação em Fotografia e Imagem) - Universidade Cândido Mendes, Rio de Janeiro. 2014.

Cuba Libre. 2015. Disponível em: <https://issuu.com/lamguimaraes/docs/cubanas>. Acesso em: 15 jan. 2018.

LANER, Luciano Coronet. Espaços da latência: da cidade ao fotográfico através da caixa preta. Dissertação (Mestrado em Artes Visuais) - Universidade Federal do Rio Grande do Sul, Porto Alegre. 2014.

MANSUR, Monica. Panoramas imaginários. In: COSTA, Ana Angélica (Org.). Possibilidades da câmera obscura. Rio de Janeiro: Projeto Subsolo; Funarte; SMC-R], 2014. 


\section{Dossiê}

MAUES, Dirceu da Costa. Caixa de ver - (Des)construção do dispositivo: invenção da paisagem. Dissertação (Mestrado em Artes) - Universidade de Brasília, Brasília. 2015.

SHAEFFER, Jean-Marie. A imagem precária: sobre o dispositivo fotográfico. Tradução de Eleonora Bottmann. Campinas: Papirus, 1996.

VASQUEZ, Pedro. Retratos do indizível. A epopeia fotográfica de Luiz Alberto Guimarães. In: COSTA, Ana Angélica (Org.). Possibilidades da câmera obscura. Rio de Janeiro: Projeto Subsolo; Funarte; SMC-R], 2014.

VILLAR, Maria Helena Saburido. A fotografia estenopeica revisitada: desconstrução da homologia tradicional através das dimensões sócio-culturais da tecnologia. Dissertação (Mestrado em Tecnologia) - Universidade Tecnológica Federal do Paraná, Curitiba. 2008. 